\title{
Investigating Relationships Between Learning Environment Perceptions, Motivation and Self-Regulation for Female Science Students in Abu Dhabi, United Arab Emirates
}

\author{
Jill M Aldridge ${ }^{1}$ (D) Kate Rowntree ${ }^{1}$
}

Accepted: 3 March 2021 / Published online: 6 April 2021

(C) The Author(s) 2021

\begin{abstract}
The global lack of student motivation towards learning science and gender imbalance in STEM careers provided the impetus for this study, which had two key aims: (1) to examine the influence of female students' perceptions of the psychosocial learning environment on their motivation towards and self-regulation in science learning,; and (2) to investigate the influence of their reported motivation on their self-regulation of effort. Data were collected from 338 female students in grades 6 to 9 science classes across 16 government schools in Abu Dhabi, in the United Arab Emirates. Structural equation modelling was used to explore the hypothesised relationships, which indicated that there were statistically significant relationships between learning environment perceptions, motivation and self-regulation. The results provide exigent information to both teachers, policy-makers and researchers with regard to the influences of the psychosocial learning environment on female students' motivation towards science, as well as the influence of motivation towards science on their self-regulatory behaviour within science classroom settings.
\end{abstract}

Keywords Learning environment · Motivation · Science learning · Self-regulation · Gender equity - Female students

Introduction Around the world there are calls for increased participation in science, technology, engineering and mathematical (STEM) subjects. The advancement of STEM skills and understanding is important, not only to the prosperity of nations but also to the prosperity of individuals (Podobnik, Crawford, Lichtenstein, Lipic, Wild, Zhang, \& Eugene, 2020). In countries around the world, STEM learning is promoted and, despite the importance placed

Jill M Aldridge

j.aldridge@curtin.edu.au 
on STEM subjects (Taştan, Davoudi, Masalimova, Bersanov, Kurbanov, Boiarchuk, and Pavlushin 2018), there are increasing concerns about the decline in students' motivation towards learning science (Wang, Chow, Degol \& Eccles, 2017). To compound the problem of motivating students in science, gender stereotypes make it difficult to motivate girls to pursue science subjects when they cease to be compulsory (Makarova, Aeschlimann, \& Herzog, 2019). The problem of motivating girls in STEM subjects is reflected in the workforce, where women continue to be under represented in STEM fields (WEF, 2017). According to the career choices of 15-year olds, this gender segregation could well persist into the future (OECD, 2017). The downward trend in motivation towards learning science is now widely accepted (Hellgren and Lindberg 2017), with motivating students remaining an ongoing challenge (Taştan et al. 2018). Given that gender inequality in education continues to ensure that girls are more disadvantaged than boys (UNESCO, 2016), this challenge becomes critical if we are to increase the low proportion of women in (and aspiring to take up) STEM careers (Nosek et al., 2009). Although gender differences in STEM subjects could be the results of a variety of factors, including culture, structural opportunities, equity in terms of school enrolment and parliamentary representation (Makarova, Aeschlimann, \& Herzog, 2019); to date, it remains unclear as to how female students can be successfully motivated in science lessons (Furrer, Skinner and Pitzer 2014). One factor that could be key to motivating students is a positive learning environment. The learning environment is increasingly recognised as central to a positive learning experience for students. Learning environment research has provided consistent evidence to suggest that "students learn better when they view the classroom environment more positively" (Dorman and Fraser 2009, p. 78). Within the context of science education, numerous studies have reported that perceptions of the learning environment impact on a range of science outcomes (Fraser 2014), including enjoyment (see, for example, Aldridge \& Bell, 2014; Sayed \& Fraser, 2019; Peer \& Fraser, 2015), self-efficacy (see, for example, Lee, Liang, Wu, Chiou, Hsu et al., 2020; Velaytham \& Aldridge, 2013XX) and career aspirations (Khalil \& Aldridge, 2019). Although some research has investigated the influence of learning environment perceptions on student motivation in countries such as Turkey (Kingir, Tas, Gok, \& Vural, 2013), Australia (Velayutham \& Aldridge, 2013) and Africa (Opolot-Okurut, 2010; Schulze \& van Heerdem, 2015), there is very limited research that investigates learning environment - motivation relationships in Arabic countries, and none that has focused on girls at the high school level. Examining malleable factors, such as those present in the learning environment, could therefore be an important step towards understanding how student motivation in science learning can be improved for girls in this context. Whilst motivation goes some way to understanding students' success in science, research suggests that students who employ self-regulated behaviours are more likely to succeed than their counterparts who do not. Self-regulatory functions are a distinctive component of social cognitive theory (Bandura, 1986) and, according to Zimmerman (1998, p. 73), they involve "self-generated thoughts, feelings and actions towards attaining one's goals". Since 2000, there has been a shift in thinking: moving from seeing self-regulation as predicting outcomes, to self-regulation being seen as a developing process, dependent on the situation (Boekaerts \& Corno, 2005). For example, learning environment factors could provide triggers that cause self-regulatory behaviours to change across specific contexts or domains (Boekaerts \& Cascallar, 2006; Boekaerts \& Corno, 2005). In this study, to help further understand the participation of female students in science, we included self-regulation as an important outcome of a positive learning environment. Given the global importance of science learning and the current decline in students entering scientific fields (Kang, Hense, Scheersoi \& 
Keinonen, 2018; Martin, Durksen, Williamson, Kiss and Ginns 2014), particularly girls (Makarova, Aeschlimann, \& Herzog, 2019), investigating learning environment factors in science lessons that could influence motivation and self-regulation of female students in a Middle Eastern context was perceived as warranted. Therefore, this study examines the influence of students' perceptions of their psychosocial learning environment on three specific motivation constructs within a science educational setting, as well as investigating the impact of students' motivation on their self-regulation.

\section{Conceptual Framework}

This study tested an explanatory model exploring relationships between the three constructs: learning environment, motivation and self-regulation (depicted in Figs. 1 and 2). In this section, the foundations for these hypotheses are described and the constructs operationalised.

\section{The Hypotheses}

Given the length of time students spend in classrooms, as well as consistent findings that students' perceptions of their learning environment influence a range of outcomes (see for example, a review by Fraser 2014), it is logical to suggest that psychosocial aspects of the learning environment may influence students' motivation towards learning science, as well as their self-regulation of effort. However, to date, only limited research exploring these relationships has been carried out with female students in non-Western settings. The first two hypotheses (depicted in Fig. 1), therefore, were that a direct relationship would exist between the four learning environment factors, the three motivation factors $\left(\mathrm{H}_{1}\right)$ and self-regulation of effort $\left(\mathrm{H}_{2}\right)$. Motivation has been found to predict self-regulated behaviour, rather than the other way around (see for example, Andrade and Heritage 2017; Zimmerman and Schunk 2008). Although other researchers have suggested a more complex relationship between motivation and self-regulation (Efklides 2014), these relationships prompted the third hypothesis (depicted

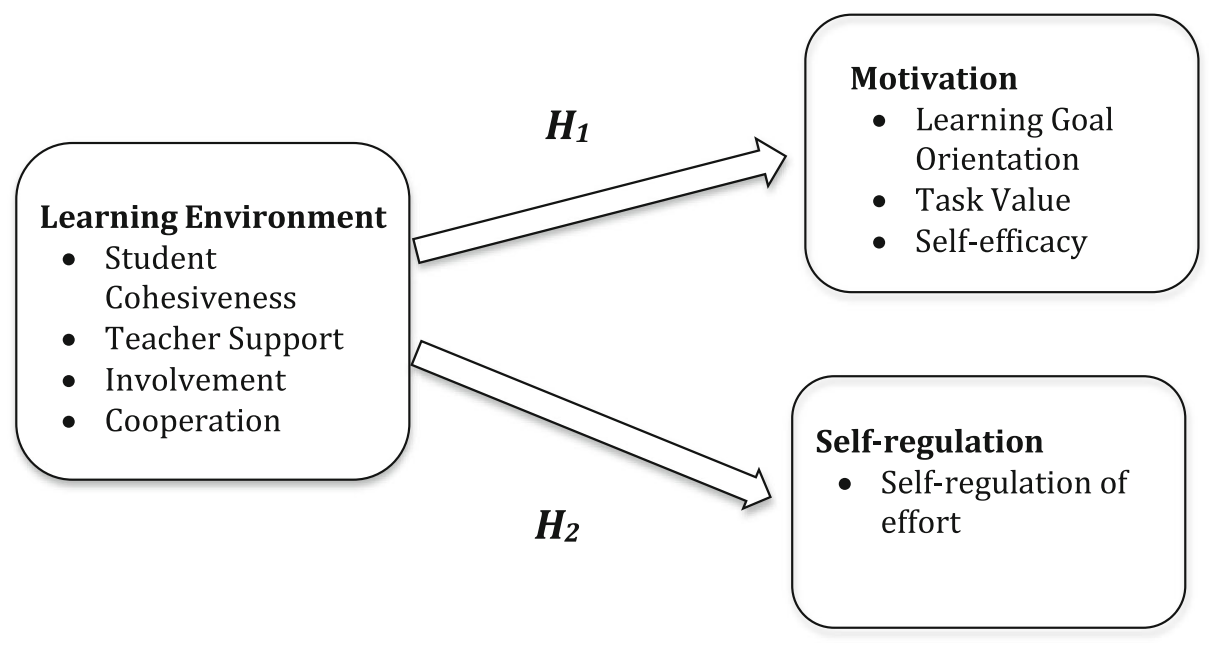

Fig. 1 Hypothetical research model for Hypotheses 1 and 2 
in Fig. 2): that there would be a direct relationship between the three motivation factors and self-regulation of effort in science learning $\left(\mathrm{H}_{3}\right)$.

\section{Operationalising the Constructs}

\section{Learning Environment}

The learning environment is the context in which learning takes place, and includes psychological, social, emotional and cultural influences (Afari, Aldridge, Fraser, and Khine 2013). At the heart of the learning enviornment are the students and the teachers who, combined with elements related to the way in which teaching and assessment takes place, provide a system within which learning occurs. There is much evidence to suggest that different elements of the psychosocial learning environment and the dynamics between them (such as the relationships between students) are important predictors of students' cognitive and affective outcomes. Strong and consistent evidence from a range of studies carried out in different countries suggests that the learning environment influences student motivation (see for example, Hanrahan, 1998; Opolot-Okurut, 2010; Tas, 2016) and self-regulation (see for example, Veyalutham \& Aldridge, 2013; Veyalutham, Aldridge \& Afari, 2013). These findings provide support for the first two hypotheses, which were the psychosocial learning environment would influence students' motivation towards learning science $\left(\mathrm{H}_{1}\right)$ and self-regulation of effort $\left(\mathrm{H}_{2}\right)$. This section operationalises and justifies the selection of the four learning environnment constructs used in this study: student cohesiveness, teacher support, involvement, and cooperation. The relationships between students is an important dimension of the learning environment. An environment where students feel socially accepted and supported by their peers is important for learning because they are more likely to take risks in their learning (Aldridge, Bell, Fraser and Dorman 2012), demonstrate fewer conduct problems and emotional difficulties (Oldfield, Humphrey and Hebron 2016) and enjoy the learning process more (Blum, McNeely, and Rinehart 2005). Given the importance of student relationships, students' perceptions of social cohesion were predicted to provide cogent information with respect to their motivation towards learning science. The relationship that teachers have with their students and the level of support that they provide is at the heart of a positive learning environment. This relationship is demonstrated through the rapport that is built up and the interactions that teachers share with their students (Dorman 2008). Given that this relationship is critically important to effective teaching and learning (Aldridge et al. 2012), this dimension was included as a measure of the learning enviornment. It was hypothesised that the quality of the relationship between the teacher and student would influence student motivation. As well as relationships, the learning and assessment design also impact on the learning environment.

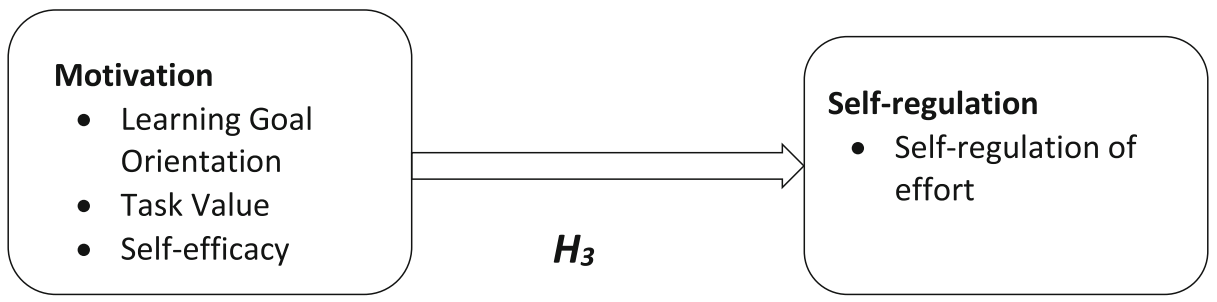

Fig. 2 Hypothetical research model for Hypothesis 3 . $* * * p<.001$; $* * p<.01$; $* p<.05$; paths that were not significant are not shown 
As such, the instructional tasks set by the teachers will dictate the degree of involvement or level of participation in the learning process. This level of involvement influences the experiences of students and impacts on the learning environment (Aldridge, Fraser, and Huang 1999). Given that increased levels of involvement have been linked to increased motivation and self-regulation (Velayutham and Aldridge 2013), this scale was included. The cooperation scale involves "the extent to which students cooperate rather than compete with one another on learning tasks" (Dorman 2008, p. 183). Johnson and Johnson (2014, p. 843) argue that “...valuing cooperation results in greater psychological health and higher self-esteem than does competing with peers or working independently." The strength of evidence suggesting that cooperative learning has a positive effect on a range of learning outcomes (Johnson, Johnson and Stanne 2000), led to its inclusion in our study.

\section{Motivation}

Common definitions of motivation involve a reaction to circumstances or events that are either internally or externally stimulated. In science education, this is important, given that research findings suggest that "motivation provides an internal state that arouses, directs, and sustains students' behaviour toward achieving certain goals" (Glynn, Taasoobshirazi and Brickman 2007, p. 1089). Three important facets of motivation theory were utilised in this study: learning goal orientation, task value, and self-efficacy. Goals, according to goal theory, give meaning or purpose to an activity (Kaplan and Maehr 2007). For learning goal orientation, the meaning behind the goal seeks "to develop competence and task mastery" (Elliot, Murayama, and Pekrun 2011, p. 632). Students with learning goal orientations seek challenge and persevere when presented with difficulties (Dweck and Leggett 1988). Within a science education context, learning goal orientation examines the degree to which students participate in science lessons for the purpose of "learning, understanding and mastering science concepts" (Velayutham, Aldridge and Fraser 2011, p. 9). Given the positive relationship between learning goal orientation and positive learning outcomes, this construct was considered meaningful in this study. Task value is related to the importance, interest and utility of a given task. The perceived value of a task, therefore, determines task choice; that is, students engage in tasks that they value positively and avoid tasks with a perceived negative value (Wigfield and Eccles 2000). Research findings support the theoretical link between the value ascribed to a task and resulting cognitive and affective outcomes, as well as the effort students apply to that task (Nagengast, Marsh, Scalas, Xu, Hau and Trautwein, 2011). The breadth of the research and consistency of findings concerning task value supported the inclusion of it as a motivational construct for this study. Self-efficacy beliefs are related to the confidence a student has in his/her own ability to successfully perform tasks (Bandura, 1986). Students with strong self-efficacy anticipate success and view learning tasks as opportunities in which to be challenged. These students recover quickly from setbacks and attribute failure to insufficient preparation or readiness rather than an inherent failure (Pajares and Schunk 2001). The past research findings that suggest that self-efficacy beliefs influence students' learning outcomes (BartimoteAufflick, Bridgeman, Walker, Sharma and Smith 2016; Jinks and Lorsbach 2003), made this an important construct for this study. 


\section{Self-Regulation}

An important component of learning is a student's ability to self-regulate their actions. In this study, it was hypothesised that both the psychological learning environment $\left(\mathrm{H}_{2}\right)$ and students' motivation towards learning science $\left(\mathrm{H}_{3}\right)$ would influence their self-regulation. Our study drew on Pintrich and De Groot's (1990) model of self-regulation, which includes the management and control of effort. Researchers argue that, while research has investigated metacognitive strategies and the use of cognitive strategies, the management and control of effort has largely been neglected (Boekaerts, 1993; Boekaerts \& Cascallar, 2006; Pintrich, 2000b). Importantly, the self-regulation scale used in this study was designed to also measure an aspect of selfregulation often neglected in the research-motivation for learning and effort investment (Velayutham et al., 2011). Self-regulation of effort, therefore, is the extent to which students control and regulate their effort when learning specific tasks. Research evidence suggests that self-regulation plays a strong role in student learning (Blair, Ursache, and Vernon-Feagans 2015; Schmitt, McClelland, Tominey, and Acock 2015), making it an important outcome, particularly in terms of life-long learning. There is, however, only limited research that has examined the impact of motivation on self-regulation (Velaytham \& Aldridge 2013). Therefore, this study builds on previous research by examining the influence of both the learning environment perceptions and student motivation on self-regulation among female students in a Middle-Eastern setting.

\section{Method}

In this section, the methods used in this study are reported, including the sample, instruments used for data collection and analyses procedures.

\section{Sample}

The sampling process for this study was driven by teacher selection. Science teachers in Abu Dhabi government schools, at the time of this study, were implementing cooperative learning strategies, embedded within the science curriculum, as part of the school reform efforts taking place. However, this was happening to different degrees across the emirate, with some teachers implementing cooperative learning strategies well and others continuing to use a more teacher-centred approach. To facilitate the selection of teachers, a rubric was utilised by the second author. The rubric examined various aspects that can be associated with moving from a more teacher-centred approach to a more cooperative learning approach, and was broken down into five levels; with the higher levels being associated with more studentcentred, collaborative activities (see the appendix for a copy of the rubric). The rubric was used to identify teachers using cooperative learning to different degrees. As such, the sampling was purposeful to ensure that the generalisability of the findings was increased. Although a balanced sample was sought, an extensive sampling process identified only five teachers as using cooperative learning strategies effectively. Therefore, the sample involved five teachers who used cooperative learning strategies at the higher levels of the rubric (e.g. levels 4 to 5) and the remaining teachers who used cooperative learning at varying degrees across the lower levels of the rubric. 
Using this method, a total of 16 classes from six all-girl middle schools across the Abu Dhabi emirate were selected, providing a sample of 338 female students of whom 69 were in grade 6, 34 were in grade 7, 65 were in grade 8 and 170 were in grade 9 .

\section{Instruments}

The data were collected using two instruments: the Students' Adaptive Learning Engagement Survey (SALES); to assess students' motivation and self-regulation, and a modified version of What Is Happening In this Class (WIHIC); to assess students' perceptions of the learning environment.

\section{Learning Environment}

The What Is Happening In this Class? (WIHIC; Aldridge, Fraser, and Huang 1999) was developed to assess students' perceptions of the classroom climate. The WIHIC was appropriate for our study because of the evidence supporting its validity and reliability in a range of contexts and countries (Fraser 2014), as well as its suitability for the education level and subject focus of the sample in this study. For the purpose of this study, four of the seven WIHIC scales (each made up of 8 items) were used: student cohesiveness, teacher support, involvement and cooperation. A five-point frequency response format of 'almost never', 'seldom', 'sometimes', 'often' and 'almost always' was used. When administered with the sample (reported above), the data analysis provided strong support for the reliability and validity of the four-scale version of the WIHIC. Principal axis factor analysis with oblique rotation (involving the 32 items of the WIHIC) extracted four succinct sets of factors. As recommended by Field (2009), each item had a factor loading of at least .40 on its own scale and less than .40 on any other scale. The Cronbach alpha reliabilities ranged from .85 to .91 for individual WIHIC scales. For each scale, the Cronbach alpha, a description and a sample item, can be found in Table 1 .

Table 1 Scale description and sample item for modified WIHIC

\begin{tabular}{|c|c|c|c|}
\hline Scale name & $\alpha$ & Scale description & Example item \\
\hline Student cohesiveness & .89 & $\begin{array}{l}\text { The extent to which... } \\
\text { students know, help, } \\
\text { and are supportive } \\
\text { of one another. }\end{array}$ & $\begin{array}{l}\text { I make friendships among } \\
\text { students in this class. }\end{array}$ \\
\hline Teacher support & .91 & $\begin{array}{l}\text { the teacher helps, befriends, } \\
\text { trusts, and shows interest } \\
\text { in students. }\end{array}$ & $\begin{array}{l}\text { The teacher goes out of her } \\
\text { way to help me. }\end{array}$ \\
\hline Involvement & .85 & $\begin{array}{l}\text { students have attentive interest, } \\
\text { participate in discussions, } \\
\text { perform additional work, } \\
\text { and enjoy the class. }\end{array}$ & $\begin{array}{l}\text { My ideas and suggestions } \\
\text { are used during class } \\
\text { discussions. }\end{array}$ \\
\hline Cooperation & .86 & $\begin{array}{l}\text { students cooperate rather than compete } \\
\text { with one another on learning tasks. }\end{array}$ & $\begin{array}{l}\text { I work with other students } \\
\text { on assignments in this class. }\end{array}$ \\
\hline
\end{tabular}

Source: Adapted from Aldridge, Fraser, and Huang (1999) with permission 


\section{Motivation and Self-Regulation}

The Student Adaptive Learning Engagement in Science (SALES; Velayutham et al. 2011) was developed to assess students' motivation and self-regulation in science learning. This instrument was chosen because first, it was designed to assess students' motivation in science education, the same context as our study; second, it was created to be implemented at the same grade level as the sample in the study; and finally, past findings report sound validity and reliability (Velayutham et al. 2011). The survey consists of four scales: three that assess motivational beliefs (learning goal orientation, task value and self-efficacy) and one that assesses students' self-regulation. Each scale has eight items. The items are responded to on a five-point Likert scale of 'strongly disagree', 'disagree', 'not sure', 'agree' and 'strongly agree'. When used with this sample of students, principal axis factor analysis with oblique rotation involving the 32 items (eight items in each of four scale) extracted the four a priori sets of factors: learning goal orientation, task value, self-efficacy and self-regulation. All items loaded .40 or higher for their own scale and below .40 on all other scales with one exception (item 24 for the self-efficacy scale, which was removed for all subsequent analyses). Furthermore, the Cronbach alpha coefficients ranged from .84 to .91 for different scales. The Cronbach alpha, and a description and sample item for each scale can be found in Table 2 .

\section{Translation of Questionnaires}

Arabic was the first language for the participants of this study. To provide as much language support as possible, a dual language (English and Arabic) version of the survey was provided. Translation of the two surveys involved a process of back-translation (recommended by Ercikan 1998). In this process, the initial translation was completed by an expert in both English and Arabic who was familiar with the educational concepts within the scales. The Arabic version was then back-translated into English by an independent expert who was not familiar with the questionnaires. This enabled a comparison of the two English versions to be made to ensure that key concepts within the scales were consistent in meaning. For items that were inaccurate, inconsistent and/or overly complex, changes were made in consultation with both translators. In the final version, a dual language format was provided. A copy of the surveys and instructions is available on request.

Table 2 Alpha values, description and sample item for each SALES scale

\begin{tabular}{|c|c|c|c|}
\hline Scale name & $\alpha$ & Scale description & Example item \\
\hline $\begin{array}{l}\text { Learning goal } \\
\text { orientation }\end{array}$ & .91 & $\begin{array}{l}\text { A student's desire to develop competence, } \\
\text { focus on learning, understand and master tasks }\end{array}$ & $\begin{array}{l}\text { In this class, one of my goals is to learn } \\
\text { new science content. }\end{array}$ \\
\hline Task value & .90 & $\begin{array}{l}\text { The value a student places on a learning task as } \\
\text { important, interesting and useful }\end{array}$ & $\begin{array}{l}\text { In this science class, what I learn can } \\
\text { be used in my daily life. }\end{array}$ \\
\hline Self-efficacy & .88 & $\begin{array}{l}\text { The belief a student holds about their own } \\
\text { competencies }\end{array}$ & $\begin{array}{l}\text { In this science class, I can master the } \\
\text { skills that are taught. }\end{array}$ \\
\hline Self-regulation & .84 & $\begin{array}{l}\text { The degree to which a student manages or } \\
\text { controls his/her behaviour in the pursuit of } \\
\text { their } \\
\text { learning goals. }\end{array}$ & $\begin{array}{l}\text { In this science class, even when skills } \\
\text { are uninteresting, I keep working. }\end{array}$ \\
\hline
\end{tabular}

Source: Adapted from Velayutham, et al. (2011) with permission 


\section{Data Analysis}

Structural equation modelling (SEM) was used to help test the hypothesised model. Given that SEM provides the means to develop complex path models with direct and indirect effect, it was considered suitable for the present study. As data was collected by the second author, checks were made at the point of collection. This ensured that there was no missing data. In the first instance, confirmatory factor analysis (CFA) was used to check for violations in the data, support the convergent and discriminant validity and to determine whether the research model fitted the data. Convergent validity was evaluated using item reliability, composite reliability (CR) and average variance extracted (AVE). Item reliability was assessed by using an items factor loading onto the underlying construct. For CR, we used Nunnally and Berstein's (1994) recommended cut-off of at least .7. For AVE, Fornell and Larcker's (1981) recommendation of .50 or higher was used to satisfy convergent validity. Discriminant validity, used to assess the degree to which the constructs were empirically different, involved examining the correlation between the constructs. As suggested by Fornell and Larcker (1981), the square root of the AVE for each construct should be higher than the correlations shared among that construct and the other constructs in the model. The structural model was evaluated through examination of the overall goodness of fit, including an explanation of the variance in the dependent variables using the squared multiple correlations $\left(R^{2}\right)$. To test the hypotheses, the model fit was examined. Because the Chi square goodness of fit is sensitive to sample size, the model-fit was determined using Chi square divided by the degrees of freedom. In addition, model fit was examined using Comparative Fit Index (CFI), Tucker Lewis Index (TLI) and Root Mean Square Error of Approximations (RMSEA). Table 3 provides the recommended guidelines for model fit that were used in this study. The relationships between the four WIHIC scales and the three motivation scales (learning goal orientation, task value, self-efficacy) and selfregulation scale were explored by determining whether a particular parameter was able statistically to estimate significantly the potential relationships between the hypothetically correlated scales.

\section{Results}

\section{Confirmatory Factor Analysis}

The descriptive statistics supported univariate normality in the data. The skewness indices for all of the scales in model ranged between -2.07 and -0.61 , with the kurtosis indices ranging

Table 3 Structural model goodness-of-fit

\begin{tabular}{llll}
\hline Model fit indices & Values & Recommended guidelines & References \\
\hline$\chi^{2}$ & $2862.44 ; p<.001$ & Non-significant & (Kline 2010; McDonald and Ho 2002) \\
df & 1866 & & \\
$\chi^{2 / d f}$ & 1.53 & $<3$ & (Kline 2010) \\
TLI & .91 & $\geq .90$ & (Klem 2000; McDonald and Ho 2002) \\
CFI & .92 & $\geq .90$ & (Hair et al. 2010) \\
RMSEA & .04 & $<.08$ & (Hair et al. 2010) \\
SRMR & .05 & $<.08$ & (Hair et al. 2010) \\
\hline
\end{tabular}


between -0.34 and 4.67. Based on the recommendations of West, Finch, and Curran (1995), these results were considered to be acceptable. The standard deviations ranged between 0.77 and 1.06, demonstrating a narrow spread around the skewness and kurtosis. The results of confirmatory factor analysis indicated that the factor loadings and constructs of the model were reliable. Standardised factor loadings were all above .60 (with the exception of one item that had a loading of .53). CR for each factor ranged from .89 to .91 , thereby exceeding the recommended criterion of greater than .70 (see Table 4). The AVE for each factor, reported in Table 3, ranged from .51 to .57 , meeting the requirements of at least .50 , thereby confirming convergent validity. Finally, the square root of the average variance extracted was higher than the correlations shared among the construct and the other constructs in the model, thereby supporting the discriminant validity (see Table 4). Given these findings, the measurement model was considered to have adequate convergent and discriminant validity.

\section{Structural Modelling}

The model fit indices (reported in Table 3) all indicated a good fit, further confirming the structural model as suitable for SEM purposes. Furthermore, for each scale, the $R^{2}$ value was higher than the minimum requirement of 0.10 (see Table 5). These results suggest that students' perceptions of their learning environment explained $31 \%$ of the variance in learning goal orientation, $42 \%$ of the variance in self-efficacy, $39 \%$ of the variance in task value and $69 \%$ of the variance in self-regulation, with self-regulation demonstrating the most analogous relationship between the variables. Analysis of the path coefficient and $p$ value for the 19 hypothesised relationships resulted in 10 of the 19 hypotheses being supported $(p<.001)$. Figure 3 portrays the statistically significant relationships (non-significant relationships have been omitted) between the learning environment, motivation and self-regulation. All of the statistically significant relationships were positive in direction. The association for one of the four learning environment variables, student cohesiveness, was not statistically significant for any of the outcome variables.

\section{Influence of the Learning Environment on Student Motivation (Hypothesis 1)}

The first hypothesis predicted that students' perceptions of their learning environment would positively influence their motivation in terms of learning goal orientation, task value and self-

Table 4 Discriminant validity for the measurement model

\begin{tabular}{lllllllllll}
\hline Constructs & CR & AVE & LGO & TV & SE & SR & SC & TS & I & C \\
\hline Learning Goal Orientation (LGO) & .91 & .57 & $\mathbf{( . 7 5 )}$ & & & & & & & \\
Task Value (TV) & .90 & .52 & $.68^{* *}$ & $(.72)$ & & & & & & \\
Self-Efficacy (SE) & .89 & .52 & $.61^{* *}$ & $.64^{* *}$ & $(.72)$ & & & & & \\
Self-Regulation (SR) & .89 & .51 & $.60^{* *}$ & $.61^{* *}$ & $.70^{* *}$ & $(.71)$ & & & & \\
Student Cohesiveness (SC) & .90 & .53 & $.27^{* *}$ & $.26^{* *}$ & $.32^{* *}$ & $.35^{* *}$ & $\mathbf{( . 7 3 )}$ & & & \\
Teacher Support (TS) & .91 & .55 & $.21^{* *}$ & $.32^{* *}$ & $.35^{* *}$ & $.42^{* *}$ & .08 & $\mathbf{( . 7 3 )}$ & & \\
Involvement (I) & .90 & .54 & $.26^{* *}$ & $.34^{* *}$ & $.38^{* *}$ & $.42^{* *}$ & $.35^{* *}$ & $.53^{* *}$ & $(.74)$ & \\
Cooperation (C) & .90 & .53 & $.26^{* *}$ & $.36^{* *}$ & $.37^{* *}$ & $.43^{* *}$ & $.51^{* *}$ & $.36^{* *}$ & $.57^{* *}$ & $\mathbf{( . 7 3 )}$ \\
\hline
\end{tabular}

$* * p<.01$

The bold elements in the main diagonal are the square roots of the AVE and the off-diagonal elements are the shared variance (factors' correlations) 
Table 5 Coefficient of determination $\left(R^{2}\right)$ of the endogenous variables

efficacy. With regard to this hypothesis, the results indicated that seven out of a possible twelve relationships had a direct, positive association.

\section{Learning Goal Orientation}

Two of the four WIHIC scales were associated with students' learning goal orientation: teacher support $(\beta=0.24, p<0.001)$ and cooperation $(\beta=0.49, p<0.001)$. Of these, the cooperation scale had the greatest influence of students' learning goal orientation.

\section{Task value}

Three of the four WIHIC scales were positively associated with task value: teacher support $(\beta=0.27, p<0.001)$, involvement $(\beta=0.19, p<0.05)$ and cooperation $(\beta=$ $0.63, p<0.001)$. This indicated that if students felt supported by the teacher, involved (rather than passive) in the lesson, and cooperated with peers, they were more likely to value the task.

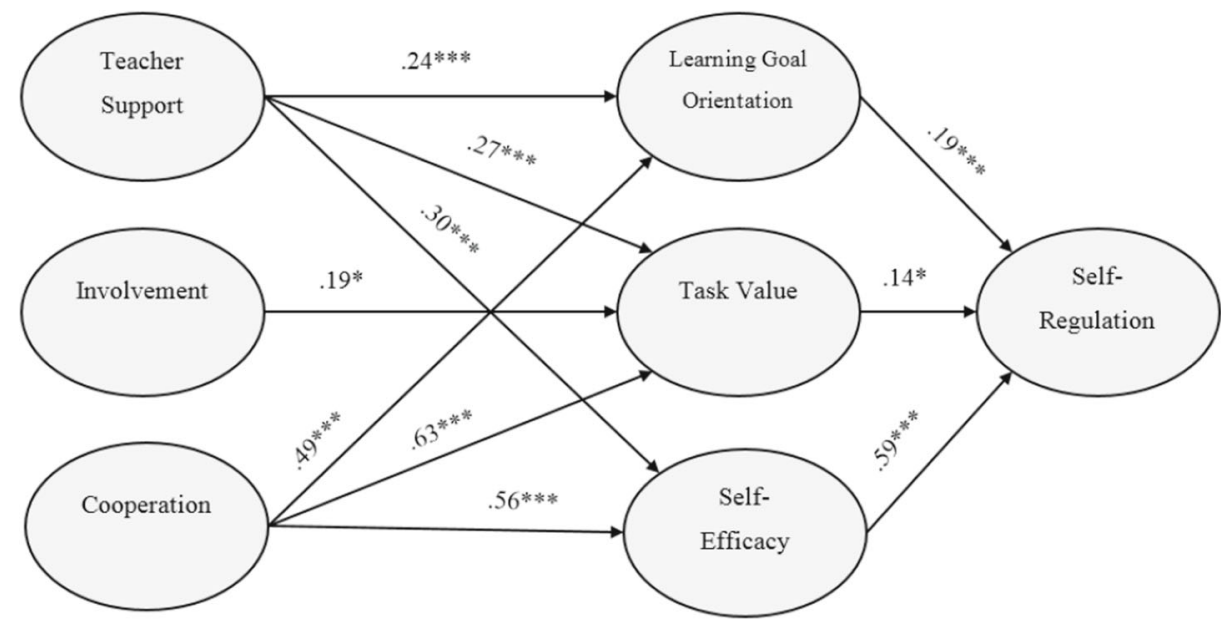

Note: $* * * p<.001 ; * * p<.01 ; * p<.05$

Paths that were not significant are not shown.

Fig. 3 Statistically significant paths for the two hypothesised research models 


\section{Self-Efficacy}

Two of the four WIHIC scales were positively associated with student self-efficacy: teacher support $(\beta=0.30, p<0.001)$ and cooperation $(\beta=0.56, p<0.001)$. As with the other relationships, the cooperation scale had the greatest influence on students' self-efficacy.

\section{Influence of the Learning Environment on Self-Regulation (Hypothesis 2)}

Contrary to the hypothesis, there was no direct, statistically significant relationships between any of the learning environment variables and students' self-regulation. However, the model explained $69 \%$ of the variance in this construct.

\section{Influence of Motivation on Self-Regulation (Hypothesis 3)}

All three motivation variables were positively and statistically significantly associated with students' self-regulation of effort: learning goal orientation $(\beta=0.19, p<0.001)$, task value $(\beta=0.14, p<0.05)$ and self-efficacy $(\beta=0.59, p<0.001)$. In this case, self-efficacy had a greater influence on self-regulation than either learning goal orientation or task value.

\section{Discussion/Implications of Results}

This study has extended previous learning environment research which, for the most part, has focused on the impact of learning environment perceptions on students' attitudes as opposed to motivation and self-regulation. Furthermore, this study examined learning environmentmotivation associations with respect to female students in a Middle Eastern context, an area of limited research. In this section, a discussion around the three hypotheses of the study is provided.

\section{Influence of the Learning Environment on Student Motivation (Hypothesis 1)}

Our hypothesis, that there would be a direct relationship between four learning environment factors and three motivation factors, was generally supported. This finding corroborates those of past studies carried out in Western settings (see for example, Chipangura and Aldridge 2017; Tas 2016) as well as a study carried out at the university level in Jordan (Alzubaidi et al. 2016), which also found relationships between the learning environment and student motivation. A significant contribution of this study, therefore, is that it identifies malleable factors within the learning environment that positively influence the motivation of female students in science classes. Specifically, three of the four learning environment constructs (teacher support, involvement and cooperation) were found to have a statistically significant influence on students' motivation.

\section{Teacher support}

The teacher support scale influenced all three motivation constructs. It is widely accepted that the teacher is central to developing a positive learning environment. As such, their interactions with students influence the learning environment, providing a role model that sets the norms 
for social interactions and attitudes towards learning as well as the acceptance of ideas and mistakes (see for example Urdan \& Schoenfelder, 2006). Our findings go further; to suggest that, for female students, the teachers' relationships with them and the subsequent influence on the learning environment are important in terms of their motivation. First, our finding of a positive relationship between teacher support and learning goal orientation, not only supports the findings of previous learning environment research (see for example Velayutham and Aldridge 2013), but also highlights the importance of teachers' emphasis on understanding, engaging with and mastering learning concepts to encourage higher learning goal orientations (Urdan, Midgley, and Anderman 1998). The findings have implications for teachers in terms of the role that they play in shaping the learning environment including the approaches to learning and the learning structures that they provide. Second, the positive influence of teacher support on task value also supports the findings of past research carried out in Western countries (see for example, Bell \& Aldridge 2014; Velayutham and Aldridge 2013) and in Jordan (Alzubaidi et al. 2016). Given that task value beliefs promote learning performance (Zhang, Hawk, Zhang and Zhao 2016) and influence the effort students apply to a range of tasks (Andrade and Heritage 2017, Nagengast et al. 2011), this finding draws attention to the important role that teachers have in helping students to value learning tasks. Our findings imply that, if female students perceive that their teacher cares about them, they are more likely to be motivated in provided tasks. According to Noddings' (1992), the qualities of a caring teacher include a positive, respectful discourse between the teacher and student that involves democratic communication styles, caring and patience. Third, the finding that teacher support influenced student self-efficacy corroborates numerous past studies (see for example, Alt 2015; Jinks and Lorbach 2003). This finding suggests that students who perceive the teacher to be supportive are more likely to report higher levels of self-efficacy. Considering the profound impact self-efficacy plays on learning outcomes (Jinks and Lorsbach 2003), the fact that the teacher-student relationship can positively influence self-efficacy levels is important, and something that educators need to be aware of. Our findings imply that the relationship with teachers is important to female students and, if it is positive, they are likely to report more positive self-efficacy. In showing a sense of caring towards students, it is important that consideration be given to the context within which the interaction between teacher and student takes place. Caring does not mean being a friend to the student but, rather, research suggests that teachers who are caring are likely to provide rules and structures while allowing a sense of autonomy (Urdan \& Schoenfelder, 2006). Our finding suggests that when girls perceive their science teacher to be friendly, understanding of their problems and to care about them, they respond more positively to the learning. For teachers wishing to motivate their students, paying attention to the student-teacher relationship is an important place to start.

\section{Involvement}

Our results indicated that female students' perceptions of their involvement in classroom activities influenced only one of the three motivation scales, task value. This finding replicates the findings of past studies in which involvement was found to have only a limited influence on student motivation (Afari et al. 2013; Alzubaidi et al. 2016; Velayutham and Aldridge 2013). Given that students had predominantly been exposed to traditional teaching methods where students' involvement largely took the form of answering questions, this was an important finding; suggesting that this change in teaching could enhance students sense of task value. 


\section{Cooperation}

The cooperation scale influenced all three motivation scales, suggesting that activities involving collaboration, rather than competition, could increase the motivation of female students. Our findings support other research that has reported similar findings (see for example, Levy, Kaplan \& Patrick 2004; Opolot-Okurut 2010). Importantly, our findings support research that reports gender differences in preferences for collaborative learning (see for example, Cen, Ruta, Powell, \& Ng, 2014), with girls tending to respond more positively to collaborative work than boys. It should be noted, however, that these positive findings with respect to collaboration could be attributed to the single-gender classroom environment. The positive influence of this learning environment construct may be attributable to the focus on cooperative learning strategies within the science curriculum that was being implemented in Abu Dhabi at the time of our study. This finding is important for policy makers in Abu Dhabi, as it implies that, for female students, the introduction of cooperative learning strategies could lead to improved motivation in science. For teachers, this finding implies that the effective implementation of cooperative learning strategies provides positive outcomes for female students. The shift from a teacher-centred to a student-centred orientation is demanding and, as the selection of teachers for this study suggests, is being done with differing degrees of success. The findings of this study imply that the successful implementation of cooperative learning is worth pursuing and, therefore, attention needs to be given to the professional development of teachers. According to McChesney and Aldridge (2019), the impact of the professional development provided in Abu Dhabi needs to consider a variety of factors to ensure that all teachers benefit.

\section{Student cohesiveness}

The results, which indicated that student cohesiveness did not influence any of the motivation constructs, differed to the results of past studies (Alzubaidi et al. 2016; Fraser, Aldridge, and Adolphe 2010). In consideration of this unexpected finding, it is possible that female students' peer orientation (the extent to which students prefer to work collaboratively) may have influenced students' perceptions of cohesion. Hancock (2004) found that students with a high peer orientation viewed working cooperatively more favourably than students with a low peer orientation. Given the cultural context in which our study took place, the peer orientation of these female students could have influenced their perceptions of social cohesiveness. Although not assessed in this study, the implication is that educators and researchers examining ways to improve student motivation might do well to consider cultural aspects of student learning.

\section{Influence of the Learning Environment on Self-Regulating Environment on Self-Regulation (Hypothesis 2)}

Our result, that none of the learning environment scales influenced students' self-regulation, differed to those of studies carried out in Western countries (Chipangura and Aldridge 2017; Velayutham and Aldridge 2013). Given that self-regulation is a developing process that is context dependent, our findings suggest that more research is needed to examine different learning environment factors that could influence self-regulation of effort in different cultural contexts (Boekaerts and Cascallar 2006). 


\section{Influence of Motivation on Self-Regulation (Hypothesis 3)}

Given that students who self-regulate their efforts are actively engaged in generating meaning when learning science (Boekaerts and Corno 2005), developing or encouraging this behaviour is important. Our results, which show that all three motivation constructs (learning goal orientation, task value and self-efficacy) were directly related to female students' selfregulation of effort, is an important finding. These results corroborate the findings of numerous past studies (see for example, Andrade and Heritage 2017; Zimmerman and Schunk 2008). The implications for this finding suggest that, by motivating students, teachers are likely to promote self-regulatory behaviours. Interestingly, of the three motivation constructs, the strongest influence on self-regulation was self-efficacy, a finding that also supports those of other studies (Bandura 1991; Dweck and Master 2008; Schunk and Ertmer 2000). Of the three motivation constructs, self-efficacy was found to be the strongest predictor of self-regulation. Although this finding was specific to female students, it supports the findings of other researchers with regard to self-efficacy being a strong predictor of self-regulation of effort within classrooms (Bandura, 1991; Dweck \& Master, 2008; Schunk \& Ertmer, 2000; Zimmerman \& Schunk, 2008). The finding, which showed that learning goal orientation was a statistically significant $(p<0.001)$ and positive predictor of students' self-regulation of effort, corroborates similar research findings with regard to the relationship between learning goal orientation and self-regulation (Alzubaidi et al., 2016; Chipangura \& Aldridge, 2017; Schunk \& Ertmer, 1999; Schunk \& Zimmerman, 1996; Velayutham et al., 2013; Velayutham \& Aldridge, 2013; Velayutham et al., 2011, 2012; Zimmerman \& Kitsantas, 2014).

\section{Limitations}

As with all studies, this study was not without limitations. These limitations, particularly those related to the sample, need to be considered when generalising the findings. First, the sample included only female students. Whilst this provides important findings with respect to girls in science classes in a non-Western setting, generalising the findings to other samples should be done with caution. Second, the sample was limited both in terms of size ( $N=338$ students in 16 classes) and in geography (drawn only from within the emirate of Abu Dhabi). Therefore, generalisations should be made with caution when considering groups in other Emirates or Arabic countries. A third limitation is the lack of qualitative information that could have provided additional causal information for the results. Finally, it is acknowledged that the use of self-reported data could have limitations in terms of the students providing responses that they consider acceptable rather than truthful.

\section{Conclusion}

Our findings support the proposition that motivation, a key component of the learning process, can be influenced by malleable features of the learning environment (Urdan \& Schoenfelder, 2006). Given that there are gender differences in learning preferences (see for example, Wehrwein, Lujan, DiCarlo, 2006), our findings suggest that, for female students, enhancing elements of the learning environment (such as teacher-student relationships and involving collaborative learning) could promote motivation and, as a result, also develop students' selfregulation in science learning. Not only does our study support the findings of previous 
research carried out in Western countries but, as one of only a handful of studies carried out in the Middle East, it paves the way for future studies in Arabic countries. The findings indicate that despite the culture of the student, their perceptions of the learning environment influence their motivation towards learning. Although the role of the learning environment in student learning is being increasingly recognised, to date, only limited attention has been paid to the importance of developing a positive learning environment in teacher education and professional development programmes. These findings provide important implications for teacher educators in Abu Dhabi (where cooperative learning is being implemented), suggesting that education programmes and future professional development need to provide teachers with the knowledge to develop positive learning environments in science classrooms (including factors related to student-teacher relationships and student involvement in science lessons). Given the decline in students' motivation towards learning science (Wang, et al. 2017), and the underrepresentation of women in STEM subjects, it is important that researchers and educators continue to investigate both the reasons for this decline and solutions to reverse it. Our study provides information about how teachers might consider changing malleable factors of the science classroom learning environment to enhance the motivation and (subsequently) selfregulation of female students. These include the level of teacher support perceived by students, the extent to which the students felt involved in the learning dynamics of the classroom and the level of cooperation experienced, which were all positive determinants of students' motivation towards learning. Further, we speculate that the introduction of effective cooperative learning strategies within science learning would increase female students' levels of motivation and self-regulation.

Electronic supplementary material The online version of this article (https://oi.org/10.1007/s11165-02109998-2) contains supplementary material, which is available to authorized users.

Funding The research reported in this article was supported by an Australian Government Research Training Programme Scholarship

Open Access This article is licensed under a Creative Commons Attribution 4.0 International License, which permits use, sharing, adaptation, distribution and reproduction in any medium or format, as long as you give appropriate credit to the original author(s) and the source, provide a link to the Creative Commons licence, and indicate if changes were made. The images or other third party material in this article are included in the article's Creative Commons licence, unless indicated otherwise in a credit line to the material. If material is not included in the article's Creative Commons licence and your intended use is not permitted by statutory regulation or exceeds the permitted use, you will need to obtain permission directly from the copyright holder. To view a copy of this licence, visit http://creativecommons.org/licenses/by/4.0/.

\section{References}

Afari, E., Aldridge, J. M., Fraser, B. J., \& Khine, M. S. (2013). Students' perceptions of the learning environment and attitudes in game-based mathematics classrooms. Learning Environments Research, 16(1), 131-150.

Aldridge, J. M., Fraser, B. J., \& Huang, T. C. I. (1999). Investigating classroom environments in Taiwan and Australia with multiple research methods. The Journal of Educational Research, 93(1), 48-62.

Aldridge, J. M., Fraser, B. J., Bell, L., \& Dorman, J. P. (2012). Using a new learning environment questionnaire for reflection in teacher action research. Journal of Science Teacher Education, 23(3), 259-290. 
Alt, D. (2015). Assessing the contribution of a constructivist learning environment to academic self-efficacy in higher education. Learning Environments Research, 18, 47-67. https://doi.org/10.1007/s10984-015-9174-5.

Alzubaidi, E., Aldridge, J. M., \& Khine, M. S. (2016). Learning English as a second language at the university level in Jordan: Motivation, self-regulation and learning environment perceptions. Learning Environments Research, 19(1), 133-152.

Andrade, H. L., \& Heritage, M. (2017). Using assessment to enhance learning, achievement, and academic selfregulation. New York, NY: Routledge.

Bandura, A. (1986). Social foundations of thought and action: A social cognitive theory. Englewood Cliffs, NJ: Prentice-Hall.

Bandura, A. (1991). Social cognitive theory of self-regulation. Organizational Behavior and Human Decision Processes, 50(2), 248-287.

Bartimote-Aufflick, K., Bridgeman, A., Walker, R., Sharma, M., \& Smith, L. (2016). The study, evaluation, and improvement of university student self-efficacy. Studies in Higher Education, 41(11), 1918-1942.

Bell, L. M., \& Aldridge, J. M. (2014). Student voice, teacher action research and classroom improvement. Rotterdam: Sense Publishers.

Blair, C., Ursache, A., \& Vernon-Feagans, L. (2015). Multiple aspects of self-regulation uniquely predict mathematics but not letter-word knowledge in the early elementary grades. Developmental Psychology, 51(4), 459-472.

Blum, R. W., McNeely, C., \& Rinehart, P. (2005). Improving the odds: The untapped power of schools to improve the health of teens. Minnepolis, MN: University of Minnesota, Center for Adolescent Health and Development.

Boekaerts, M., \& Corno, L. (2005). Self-regulation in the classroom: A perspective on assessment and intervention. Applied Psychology: An International Review, 54(2), 199-231.

Cen L., Ruta, D., Powell, L., \& Ng, J. (2014). Does gender matter for collaborative learning. The Institute of Electrical and Electronics Engineers conference proceedings. Retrieved from https://www.researchgate.net/ publication/270847813_Does_Gender_Matter_for_Collaborative_Learning

Chipangura, A., \& Aldridge, J. (2017). Impact of multimedia on students' perceptions of the learning environment in mathematics classrooms. Learning Environments Research, 20(1), 121-138.

Dorman, J. P. (2008). Use of multitrait-multimethod modelling to validate actual and preferred forms of the What Is Happening In This Class? (WIHIC) questionnaire. Learning Environments Research, 11(3), 179-193.

Dorman, J. P., \& Fraser, B. J. (2009). Psychosocial environment and affective outcomes in technology-rich classrooms: Testing a causal model. Social Psychology of Education, 12(1), 77-99.

Dweck, C. S., \& Leggett, E. L. (1988). A social-cognitive approach to motivation and personality. Psychological Review, 95(2), 256-273.

Dweck, C. S., \& Master, A. (2008). Self theories motivate self-regulated learning. In D. H. Schunk \& B. H. Zimmerman (Eds.), Motivation and self-regulated learning: Theory, research, and application (pp. 31-51). New York, NY: Lawrence Erlbaum and Associates.

Efklides, A. (2014). How does metacognition contribute to the regulation of learning? An integrative approach. Psihologijske Teme, 23(1), 1-30.

Elliot, A. J., Murayama, K., \& Pekrun, R. (2011). A $3 \times 2$ achievement goal model. Journal of Educational Psychology, 103(3), 632-648.

Ercikan, K. (1998). Translation effects in international assessments. International Journal of Educational Research, 29, 543-553.

Fornell, C., \& Larcker, D. F. (1981). Evaluating structural equation models with unobservable variables and measurement error. Journal of Marketing Research, 18(1), 39-50.

Fraser, B. J. (2014). Classroom learning environments: Historical and contemporary perspectives. In N. G. Lederman \& S. K. Abell (Eds.), Handbook of research on science education (Vol. 2, pp. 104-119). New York, NY: Routledge.

Fraser, B. J., Aldridge, J. M., \& Adolphe, F. G. (2010). A cross-national study of secondary science classroom environments in Australia and Indonesia. Research in Science Education, 40(4), 551-571.

Furrer, C. J., Skinner, E. A., \& Pitzer, J. R. (2014). The influence of teacher and peer relationships on students' classroom engagement and everyday motivational resilience. National Society for the Study of Education, 113(1), 101-123.

Glynn, S. M., Taasoobshirazi, G., \& Brickman, P. (2007). Nonscience majors learning science: A theoretical model of motivation. Journal of Research in Science Teaching, 44(8), 1088-1107.

Hair, J., Black, W., Babin, B., \& Anderson, R. (2010). Multivariate data analysis (7th ed.). Upper Saddle River, NJ: Prentice-Hall.

Hancock, D. (2004). Cooperative learning and peer orientation effects on motivation and achievement. Journal of Educational Research, 97(3), 159-168. https://doi.org/10.3200/JOER.97.3.159-168. 
Hanrahan, M. (1998). The effect of learning environment factors on student' motivation and learning. International Journal of Science Education, 20(6), 737-753.

Hellgren, J. M., \& Lindberg, S. (2017). Motivating students with authentic science experiences: Changes in motivation for school science. Research in Science \& Technological Education, 35(4), 409-426. https://doi. org/10.1080/02635143.2017.1322572.

Jinks, J., \& Lorsbach, A. (2003). Introduction: Motivation and self-efficacy belief. Reading \& Writing Quarterly, 19(2), 113-118. https://doi.org/10.1080/10573560308218.

Johnson, D. W., \& Johnson, R. T. (2014). Cooperative learning in 21st century. Aprendizaje cooperativo en el siglo XXI. Anales De Psicología, 30(3), 841-851.

Johnson, D. W., Johnson, R. T., \& Stanne, M. B. (2000). Cooperative learning methods: A meta-analysis. Minneapolis, MN: University of Minnesota, Cooperative Learning Centre Retrieved from http://www. cooperation.org/pages/cl-methods.html.

Kang, J., Hense, J., Scheersoi, A., \& Keinonen, T. (2018). Gender study on relationships between science interest and future career perspectives. International Journal of Science Education, 41, 80-101.

Kaplan, A., \& Maehr, M. L. (2007). The contributions and prospects of goal orientation theory. Educational Psychology Review, 19(2), 141-184.

Khalil, N., \& Aldridge, J. (2019). Assessing students' perceptions of their learning environment in science classes in the United Arab Emirates. Learning Environments Research, 22(3), 365-386. https://doi.org/10.1007/ s10984-019-09279-w.

Kingir, S., Tas, Y., Gok, G., \& Vural, S. S. (2013). Relationships among constructivist learning environment perceptions, motivational beliefs, self-regulation and science achievement. ().Routledge, available from: Taylor \& Francis, Ltd. 325 Chestnut Street Suite 800, Philadelphia, PA 19106. doi:https://doi.org/10.1080/ 02635143.2013.825594 Retrieved from social science premium collection Retrieved from https://link. library.curtin.edu.au/gw?url=https://www.proquest.com/docview/1651849477?accountid=10382

Klem, L. (2000). Structural equation modelling. In L. G. Grimm \& P. R. Yarnold (Eds.), Reading and understanding multivariate statistics (Vol. II, pp. 227-260). Washington, DC: Americal Psychological Association.

Kline, R. B. (2010). Principles and practices of structural equation modelling (3rd ed.). New York, NY: Guilford Press.

Lee, M., Liang, J., Wu, Y., Chiou, G., Hsu, C., Wang, C., et al. (2020). High school students' conceptions of science laboratory learning, perceptions of the science laboratory environment, and academic self-efficacy in science learning. International Journal of Science and Mathematics Education, 18(1), 1-18. https://doi.org/ 10.1007/s10763-019-09951-w.

Levy, I., Kaplan, A., \& Patrick, H. (2004). Early adolescents' achievement goals, social status, and attitudes towards cooperation with peers. Social Psychology of Education, 7(2), 127-159.

Makarova, E., Aeschlimann, B., \& Herzog, W. (2019). The gender gap in STEM fields. The impact of the gender stereotype of mathematics and science on secondary students' career aspirations. Frontiers in Education, 4, 60-71.

Martin, A. J., Durksen, T. L., Williamson, D., Kiss, J., \& Ginns, P. (2014). Personal best (PB) goal setting and students' motivation in science: A study of science valuing and aspirations. Australian Educational and Developmental Psychologist, 31, 85-96. https://doi.org/10.1017/edp.2014.19.

McChesney, K., \& Aldridge, J. M. (2019). What gets in the way? A new conceptual model for the trajectory from teacher professional development to impact. Professional Development in Education, 1-19. https://doi.org/ 10.1080/19415257.2019.1667412.

McDonald, R. P., \& Ho, M. R. (2002). Principles and practice in reporting structural equation analyses. Psychological Methods, 7, 64-82.

Nagengast, B., Marsh, H. W., Scalas, L. F., Xu, M., Hau, K. T., \& Trautwein, U. (2011). Who took the 'X' out of expectancy-value theory? A psychological mystery, a substantive-methodological synergy, and a crossnational generalization. Psychological Science, 22(8), 1058-1066.

Nosek, B. A., Smyth, F. L., Sriram, N., Lindner, N. M., Devos, T., Ayala, A., et al. (2009). National differences in gender-science stereotypes predict national sex differences in science and math achievement. In Proceedings of the National Academy of Science, US (Vol. 106, pp. 10593-10597). https://doi.org/10. 1073/pnas.0809921106.

Nunnally, J. C., \& Bernstein, I. H. (1994). Psychometric theory. New York, NY: McGraw-Hill, Inc..

OECD (2017). The pursuit of gender equality: An uphill battle. Paris, France: OECD Publishing. doi: https://doi. org/10.1787/9789264281318-en.

Oldfield, J., Humphrey, N., \& Hebron, J. (2016). The role of parental and peer attachment relationships and school connectedness in predicting adolescent mental health outcomes. Child and Adolescent Mental Health, 21(1), 21-29. 
Opolot-Okurut, C. (2010). Classroom learning environment and motivation towards mathematics among secondary school students in Uganda. Learning Environments Research, 13(3), 267-277.

Pajares, F., \& Schunk, D. H. (2001). Self-beliefs and school success: Self-efficacy, self-concept, and school achievement. In R. Riding \& S. Rayner (Eds.), Perception (Vol. 11, pp. 239-266). London, UK: Ablex Publishing.

Peer, J., \& Fraser, B. J. (2015). Sex, grade-level and stream differences in learning environment and attitudes to science in Singapore primary schools. Learning Environments Research, 18(1), 143-161. https://doi.org/10. 1007/s10984-013-9142-x.

Podobnik, B., Crawford, G.C., Lichtenstein, B., Lipic, T., Wild, D., Zhang, X., \& Eugene, H. (2020). The new wealth of nations: How STEM fields generate the prosperity and inequality of individuals, companies, and countries. Chaos, Solitons \& Fractals, 141, online https://doi.org/10.1016/j.chaos.2020.110323.

Sayed, A. S. W., \& Fraser, B. J. (2019). Science classroom learning environments in Afghanistan: Assessment, effects and determinants. Educational Practice and Theory, 41(2), 5-23. https://doi.org/10.7459/ept/41.2.02.

Schmitt, S. A., McClelland, M. M., Tominey, S. L., \& Acock, A. C. (2015). Strengthening school readiness for head start children: Evaluation of a self-regulation intervention. Early Childhood Research Quarterly, 30, 20-31.

Schulze, S., \& van Heerden, M. (2015). Learning environments matter: Identifying influences on the motivation to learn science. South African Journal of Education, 35(2), 1-9 Retrieved from https://link.library.curtin. edu.au/gw?url=https://www.proquest.com/docview/1895977000?accountid=10382.

Schunk, D. H., \& Ertmer, P. A. (2000). Self-regulation and academic learning: Self-efficacy enhancing interventions. In M. Boekaerts, P. R. Pintrich, \& M. Zeider (Eds.), Handbook of self-regulation (pp. 631649). San Diego, CA: Academic Press.

Tas, Y. (2016). The contribution of perceived classroom learning environment and motivation to student engagement in science. European Journal of Psychology of Education, 31(4), 557-577.

Taştan, S. B., Davoudi, S. M. M., Masalimova, A. R., Bersanov, A. S., Kurbanov, R. A., Boiarchuk, A. V., \& Pavlushin, A. A. (2018). The impacts of teacher's efficacy and motivation on student's academic achievement in science education among secondary and high school students. EURASIA Journal of Mathematics Science and Technology Education, 14(6), 2353-2366.

UNESCO. (2016). Gender equality in education. Washington: United Nationals Educational, Scientific and Cultural Organization.

Urdan, T., \& Schoenfelder, E. (2006). Classroom effects on student motivation: Goal structures, social relationships, and competence beliefs. Journal of School Psychology, 44, 331-349.

Urdan, T., Midgley, C., \& Anderman, E. (1998). The role of classroom goal structure in students' use of selfhandicapping strategies. American Educational Research Journal, 35, 101-122.

Velayutham, S., Aldridge, J., \& Afari, E. (2013). Students' learning environment, motivation and self-regulation. In M. S. Khine (Ed.), Application of structural equation modeling in educational research and practice. Rotterdam: Contemporary Approaches to Research in Learning Innovations. SensePublishers. https://oi. org/10.1007/978-94-6209-332-4_6.

Velayutham, S., \& Aldridge, J. M. (2013). Influence of psychosocial classroom environment on students' motivation and self-regulation in science learning: A structural equation modelling approach. Research in Science Education, 43(2), 507-527.

Velayutham, S., Aldridge, J. M., \& Fraser, B. J. (2011). Development and validation of an instrument to measure students' motivation and self-regulation in science learning. International Journal of Science Education, 33(15), 2159-2179.

Wang, M. T., Chow, A., Degol, J. L., \& Eccles, J. S. (2017). Does everyone's motivational beliefs about physical science decline in secondary school? Heterogeneity of adolescents' achievement motivation trajectories in physics and chemistry. Journal of Youth and Adolescence, 46(8), 1821-1838.

WEF (2017). The Global Gender Gap Report. WEF. Retrieved on 2 November 2020 from: https:www3. weforum.org/docs/WEF_GGGR_2018.pdf.

Werwein, E. A., Lujan, H. L., \& DiCarlo, S. E. (2006). Gender differences in learning style preferences among undergraduate physiology student. Advances in Physiology Education, 31, 153-157.

West, S. G., Finch, J. F., \& Curran, P. J. (1995). Structural equation models with nonnormal variables: Problems and remedies. In R. H. Hoyle (Ed.), Structural equation modelling: Concepts, issues and applications (pp. 56-75). Newbury Park, CA: Sage.

Wigfield, A., \& Eccles, J. S. (2000). Expectancy-value theory of achievement motivation. Contemporary Educational Psychology, 25(1), 68-81.

Zhang, Y., Hawk, S. T., Xiaohui, Z., \& Zhao, H. (2016). Chinese preservice teachers' professional identity links with education program performance: The roles of task value belief and learning motivations. Frontiers in Psychology, 7, 573-584. https://doi.org/10.3389/fpsyg.2016.00573. 
Zimmerman, B. J. (1998). Academic studying and the development of personal skill: A self-regulatory perspective. Educational Psychologist, 33, 73-86.

Zimmerman, B. J., \& Schunk, D. H. (2008). Motivation: An essential dimension of self-regulated learning. In D. H. Schunk \& B. J. Zimmerman (Eds.), Motivation and self-regulated learning: Theory, research, and applications (pp. 1-30). New York, NY: Lawrence Erlbaum Associates.

Publisher's Note Springer Nature remains neutral with regard to jurisdictional claims in published maps and institutional affiliations. 